\title{
Voices from Torres Strait
}

For all of its history, Torres Strait has been a site of confluence and contestation, linking the currents of the world's two largest oceans, as well as the inhabitants of insular South-East Asia and the Pacific, and the two opposing mainlands of Australia and New Guinea.

Our book has focused on the significant encounter between the Torres Strait Islanders and Asian immigrants. In this final chapter, we proffer eight voices belonging to contemporary Torres Strait Islanders, whose parents or grandparents were members of the Asian communities featured in the preceding chapters. Their distinctly personal stories complement and contextualise the intricacies of the Chinese, Filipino, Malay, Japanese and Sri Lankan diasporic experience in Torres Strait. Multiple viewpoints emerge from these stories, a consequence of individual circumstances and life ways, as well as generational and gender differences.

The personal narratives of the prewar generation of Asian heritage illustrate vividly the choices faced by marginalised people struggling to survive and prosper in a new society they helped create at Australia's northern boundary - a society that was multicultural, yet internally segregated by race and class. For the postwar generation, a self-assured, blended form of Torres Strait-Asian identity is accentuated, informed by memories of childhood, family and community experiences; and by reflection on the myriad intersections of family, community and nation. Apparent in all the stories, however, are the challenging yet rewarding personal journeys made by Torres Strait Islanders of diverse ancestries, journeys that mirror the navigation of community boundaries, which has emerged as a defining aspect of this work as a whole.

The editors of this book offer this final chapter in sincere acknowledgement that it is the people who have shared their stories here, their families and their ancestors, who are truly the authors of the rich and remarkable Asian diasporic experience of Torres Strait. 
Eva Salam Peacock is the daughter of Batcho Mingo from Makasar, Sulawesi, Indonesia, and Annie Randolph from Darnley Island, of Torres Strait Islander, Danish and Sri Lankan descent. She was born on Thursday Island in 1924. Eva married Uley John Peacock in Mareeba during the war. She is the mother of eight children, grandmother of 24 and great-grandmother of three.

I was born on Thursday Island and grew up on Thursday Island, Wednesday Island and Hammond Island. On Thursday Island, we lived way up near the Hocking station, what they used to call Hockings Point. You go past all the boat slips, where the Japs were, down near the waterfront. We could just hop and jump into the water. Dad was a mechanic and worked on Hocking's launch engine. He could take the motor apart and fix it and put it back together. After he retired, he took us to live on Wednesday Island, where he cut timber for the pearling luggers and stacked the wood up in cords on the shore above the sand. I started school on Thursday Island, but I went to live on Wednesday Island just after I started school - I must have been about seven or eight. I didn't stay there, just went there for school holidays. We were sent to Hammond Island for school. My older sisters were married and already living there.

My mother was born on Nepean Island - you can see it from Darnley Island. Her mother, my grandmother, was a very tall woman named Balo from Darnley. That's what my mother has on her marriage certificate. My mother didn't know her own mother; she was only two years old when her mother passed away giving birth to her youngest child. My mother was Annie Randolph and she had two full sisters, Sophie and Fanny, and an adopted sister, Harriet. Mum didn't know where her own mother came from: different ones tell her this and that. She was young, and you don't know much. People tell me that Balo was one of three daughters born to Konai, a Torres Strait lady from Bumeo on Darnley Island and her Sri Lankan husband. They had three daughters: Balo, Sophie and Morabisi. Balo married Thomas Randolph from Denmark, but he died when my mother was about only 10 years old, she said. He was on his way to Thursday Island with the four girls when he died on board the Pirate - that was the name of his lugger - in 1897. After Randolph died, the girls were looked after by the Sinclairs, who were his friends. The Sinclairs took the four girls and raised them with their own family on Thursday Island. His wife wanted them. My mother told me that John Douglas attended Tom Randolph's funeral and stood there with his arms around the girls.

The Catholic religion came from the Filipino. Mum was an Anglican. She turned Catholic to marry her first husband. He wanted her to, so they could get married in the church. One thing about Sinclair, he always tried to do 
the right thing for them, because he thought if they went to White people to work and they started working, they probably wouldn't be treated well, you know. So he found jobs for them with the Coloured race. That's how they got to know the Filipinos. Harriet had a job with the Filipinos and so did Mum. I can't remember their names, but Harriet married a Filipino and went back with him to the Philippines and we never heard any more from them. I can't remember what his name was.

Mum was working for a Filipino family and that's how she met Lopez Delacruz. Everybody thinks they were two people, Lopez and Delacruz, but Lopez was his first name. Lots of people got mixed up with it. They thought, 'Oh, Mum's got so many husbands.' So that's how it came about. They had five

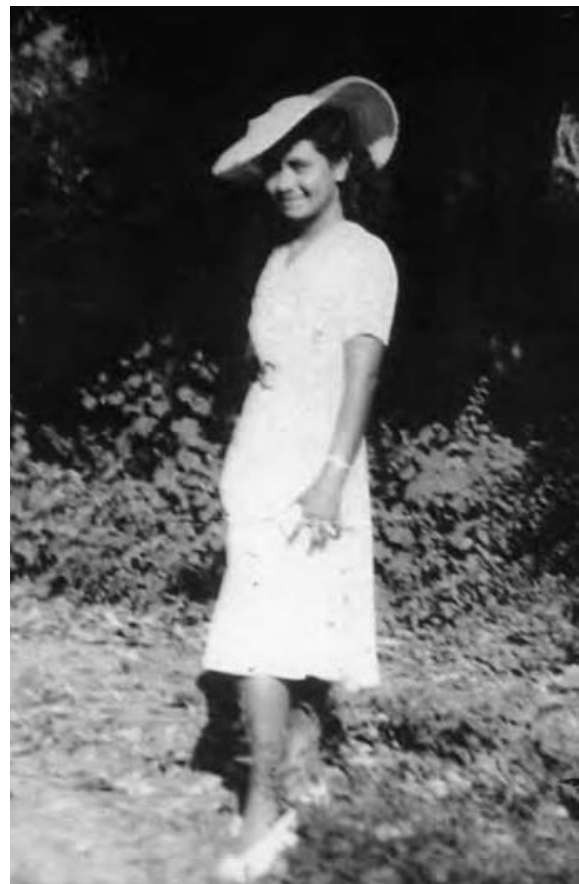

Eva Salam, taken in Darwin, c.1941. Courtesy of Eva Salam Peacock. children. And he died. He was with the pearling, he was a diver. I don't know how he died. He was in Darwin and was in a fight and was stabbed to death. He's buried in Darwin. So she was left with this young family but then Haji Salam took over. He came to her rescue and married her. That's how we got the name Salam. And she had three children with Salam. That's Siat (Josie), Amelia and Hardie. Amelia died when she was about three or four years old; she had pneumonia. Mum said it broke her heart. She told us all these sad stories. I always remember those sorts of things, you never forget it.

Haji Salam was working on the pearling. She met him and they got married and she had the three children to him. They married in the Catholic Church. I think they could marry in the Catholic Church but not in front of the altar. Haji had to be sent back to Singapore, his 10 years were up. Ten years I think they had. He said, 'Oh well, you can come with me, I'll send your fares. You'll be all right in Singapore.' So Mum was quite happy about that. She loved him. Anyway, he went home and he sent her the money, also a letter explaining that he already had two wives over there. He didn't let her know in the first place. And she didn't know how to take it. She was really upset and she said, 'No', she said she couldn't share him. She said, 'I'll stay here and starve', because 
there was no pension or anything like that in those days. Johnny was working - that's the eldest Delacruz boy. He had a job on the pilot launch. He was the only one who brought in some money and kept them from starving. But she said, 'No.' She wrote and told him that she can't go, she couldn't live that way. So that was the end of that. And so she stayed a couple of years, I suppose, and then my Dad came along and wanted to marry her. She said, 'I'm already married, I'm not divorced. I'll get into trouble if I marry again.' And he said, 'No you can marry now', because he went to the magistrate to find out. Anyway, she was afraid that she might get put in jail or something. She always thinks things that way. Poor old Dad was so disgusted, you know. He wanted his children to have his name, but Mum just left it at that. So we had to take the name 'Salam'.

Dad was a Muslim but he didn't mind if we were Catholic. He didn't mind us going to a Catholic school. He was a good provider, anyway. He'd always see that we had food and clothing. He came from the Celebes. He wasn't indentured like Salam, because Hocking got him, him and Tommy Loban. I think he came at the same time as Tommy Loban, because Ellie, his daughter, showed me a photograph of the boys that came during that time. He and Tommy Loban were very good friends. So Hocking sent them back to the place in Indonesia where they thought this British boat went down. They wanted proof to show that it did and asked them to get evidence and they did. They got the name of it, I think, the boat, and they smuggled it back to Thursday Island. So that's why they gave them the freedom to stay. He was something like an undercover spy. But he used to be proud to say he was in the Australian Navy during the war and he was on this boat - it must have been a patrol boat, the coast guard. I don't remember the name, but I remember seeing the photo. He had it on the wall, all the navy men on deck on that boat. He was there and also in the corner of that same picture there was inserted a chest photo of himself wearing navy uniform. We didn't take the picture with us when we were evacuated, we thought we were going to go back to Thursday Island after the evacuation.

Dad was a diver for Reg Hocking. They had a dormitory and the men stayed there. That was at Hocking's pearling station on Thursday Island, down where they had the boat slips. That's where they lived when they were on shore. They had a cook there, someone cooking for them, and I used to sneak up to have some curry and rice with them. It was not far, just round the point. I'd go up there to get a dinner, then I'd come home and have another one. My Dad used to be so proud of me. He used to love watching me. He looked after all the others, too, he was good to them all. He wasn't a very religious man. I didn't see him do all the things that religious Muslims do, but he wouldn't eat pork. But he loved camp pie. Everybody would look at him and say, 'You're Muslim, eh? You don't eat pig, eh?' I'd say, 'Well, what are you eating there?' He'd say, 'Meat.' 
He didn't know. He didn't drink beer, like some of the other Muslims, but he'd drink neat rum - that's a tradition from the navy.

When I left Hammond Island, I was about 14. I stayed one year on Thursday Island and I worked for Jenap Jia. Jenap was part-Islander and part-Malay and her sister, Doseena, married Assan, who was a Mohammedan priest. She had a laundry and she used to do all the laundry from the ships that came in to the island, the coastal boats. She wasn't the Jenap who is well-known for her long soup. Sang Kee was the one who made the long soup, the Chinese man. He was very, very famous for his long soup. He married Atima Ahwang. We all went to see them get married but he ran away, he cleared off, but they did marry. I was only very young at the time. They weren't young. She already had her children then.

Mrs Jenap lived in town, not far from the town hall. Yokohama was near the boat slips, near the water. The road went through where the Japs were to get to town. Malaytown was more or less across the road, the tarred road, from Japtown, going down towards the point. The Malays were on that side of the road, the Japs were on the other side, near the water. The Japs were closer to the water, because they worked on the boats. The Chinese didn't live down there, they were more or less going towards the Catholic Church way. Mainly the main street, they were, on Douglas Street. You know where the picture show was? Well, just around there. Chee Quee had that shop near the picture show. And down further, across the road that goes to the water, that's where another Chinese shop was. And Chinese across the road. Mendis was across from the Metropole Hotel. It later burned down. There was another Chinese shop, Lai Foo, up from the jetty and Mendis was along there. There was another Sri Lankan there, the dentist Saranealis. He was not far from the Metropole Hotel, on Douglas Street. The Europeans lived mostly up behind the town, going towards the state school, along that area, and up towards the church. There was the Grand Hotel up on the hill, and there was a Burns Philp shop down from that. And there was another hotel down there, too, McNulty's Hotel. There must have been everybody from around the world living there on that little island.

Monica Walton Gould was born on Thursday Island in 1927, the daughter of William Walton and Gregoria (Guria) Assacruz. Of Torres Strait Islander, Aboriginal, Filipino and English heritage, she married Harold Andrew Gould in Brisbane after the war. Monica has eight children and 17 grandchildren.

I was born on Thursday Island. I don't know if it was in hospital or at home, probably at home. We lived in John Street, not in Malaytown. Malaytown was up the other end past the Post Office. John Street was nearer the shopping 
centre, in Douglas Street, in the middle. We didn't go down to Malaytown. In our days, Catholics mixed only with Catholics. I don't know why. There was something about religion in those days.

I remember that house we lived in in John Street. It had bare walls, bare floors. We slept on the bare floors on mats, on island mats. That place was fairly big. It was lowset, but there was enough room just to crawl under. We used to crawl under and hide, you know, play hide and seek. We had no fear of spiders or snakes or anything like that. The house had wooden stumps, I remember, and wooden floors and we used to put the mats down at night to sleep. Mum rolled them up in the morning; she was very tidy and clean and I think she used to just roll them up and put them away until night-time. But I remember that house in John Street. This was before myself and my four sisters had to go to the convent for school. I was five, that was the normal age. We boarded at the convent with lots of other girls. I boarded at the convent night and day - I hated it. We worked very hard. We were on our hands and knees scrubbing the wooden floors and verandahs of the presbytery with a scrubbing brush. We used to do the washing in a wood copper, turning a huge handle for the nuns' habits and the priests' habits and vestments. The senior girls starched and ironed the nuns' veils. After I went to the convent to board to go to school, Mum and Dad shifted to Horn Island, and we just went home for school holidays.

Mum was always busy, cooking dampers, cooking the fish, cooking the rice. I didn't know her parents, they weren't alive by then. Mum never spoke about her family. Dad was a very strict man and he had this little sailing boat, Valmay. Dad used to go across to Thursday Island every day to work and then he'd come back and we'd see his sailboat getting closer and closer to Horn Island and we'd say, 'Here's Daddy, here's Daddy coming. Wonder if he's got lollies for us.' And he did have lollies for us. Dad worked as a wharf labourer and at one stage he worked for Customs. He used to bring back sacks of potatoes and onions in the boat from Thursday Island, but we had our own vegetables, sweet potatoes and fruit.

Dad sometimes used to make tuba; he was no innocent. I remember seeing him take a hanging bunch of coconut blossoms, tying them all together and bending them over an earthenware pot. The juice dripped into the pot and, when it was fermented enough, they drank it. Dad used to be very happy some evenings. Mum asked him to keep some of it for her to ferment more to make vinegar. She used to make coconut oil to wash our hair. You let it boil and boil and it turns into coconut oil. You can cook with it, use it on the skin to counteract the heat, and use it for washing your hair.

There was a well where Daniel Hodges lived on Horn Island; as far as I know, that was the only well in that vicinity. My mother used to get water 
from the well in a bucket to do her washing, because it was fresh water, drinking water. We also had two water tanks attached to our house. Mum used to get the water out of the well, fill the tub and do the washing. She got the bucket with the rope on the handle and she'd somehow manage to tip it and get the water up. No problems with water, the well was always full.

The two Canendo brothers - they were much older than us — they used to go crayfishing and they'd catch a lot of crayfish and muddies (mudcrabs) and they'd share them, like all the families would share. Dad used to go fishing, take Valmay out in the passage, just straight out from our place. We weren't interested in whether he caught fish, all we were interested in was having a swing on the tree and running around and swimming. Then Dad would come back and Mum would have the rice cooked and Dad cleaned the fish and scaled the fish - I can still see it. They had an open fire downstairs and Mum used to roast them over the hot coals. It was really tasty. I told my doctor this and she said, 'That's what gave you the start of a healthy life, having fish from the start of your life.'

I think it was Mr Vidgen — he owned a lot of cattle — who had a place there where they slaughtered the animals for the meat for the butchers. Dad used to go and help Mr Vidgen put the bulls in the shed. Not far from the slaughter yards there were lots of mango trees. I think they were planted, there were lots of them there. The Filipino men might have planted them. There were posts nearby, as if there were houses there once, near the slaughter yards at the same end as Tiyo Dualdo. I remember all these mango trees; they were special mangoes, not the ordinary plain mangoes, and very, very sweet. The skins were just really dark green and we called them 'black mangoes'. We'd race along to where we knew the mangoes were and give the lowest branches a shake and the ripe mangoes would fall down and we'd pick them up. Just a few and we were right. We were never, ever hungry. I saw some again in 1998 when my sister and I went up to Thursday Island. They were growing in a vacant allotment between the Rainbow Motel and See Kee's shop. We used to look at the trees, just laden with these mangoes. And if we had stayed on for about another month, I think we would have had a mango feast.

When we were home for school holidays, my sisters and I used to play with Francis Seden. We'd have breakfast and go over to Francis's place. They lived down towards the other end of the island, where Tiyo Dualdo lived. Francis was an only child. His stepfather had made him a little boat, just big enough to fit two or three of us children. At the back of their house was a sort of a lagoon and there was a creek leading up to this lagoon. We would play all day when the tide was in. Mum never said to us, 'Be home by four' or 'Be home by five' or anything like that. I think because she knew we weren't in any danger. 
Those days were different. And, at the end of the day, we just went home, maybe because we were tired and needed to jump in the tub and were looking forward to Mum's fish and rice. We lived on rice, even in the convent. After supper we'd sit around with the kerosene lamp and read comics. All of us sisters and Reggie and Gertie Lee, they'd come over and read comics with us. Then they'd run back home, 'See you, see you, yawo.' And that was our life.

Kyôzô Hirakawa originated from Okinawa and came to Thursday Island in 1958 and in 1960 he married Kathleen Seden. He was naturalised in 1965. Kyôzô and Kathleen went on to have five children and currently have eight grandchildren. Kyôzô is a crayfisherman and, during the off-season, he stays home and often looks after his grandchildren.

I came to Thursday Island with other Okinawan men in 1958. We worked in the pearling industry and stayed in the dormitory. Many of us were not happy with the contracts under which we were employed and so many returned to Okinawa after about one year. I came back to Thursday Island in 1960 with another friend and worked with another pearling company. I worked on a boat with six other people. I met my wife then, who was working for the same company.

At the time, Thursday Island had a very multicultural population and I was able to mix with many cultural groups. Although some attitudes towards Japanese people were difficult, this changed when Australia's relationship with Japan changed as Japanese manufactured goods were introduced.

There are not enough Okinawans to form a club on Thursday Island. When I first arrived on Thursday Island, there were about 160 there. They made shamisen (stringed instruments) and sang songs thinking about Okinawa, but I was never, never homesick. Maybe I was too young. Now there are no shamisen, no music, but I still listen to cassette tapes of Okinawan songs.

While Okinawan festivals are not celebrated, the three remaining Okinawans stick together. Sometimes we use Okinawan language with them. Nowadays when speaking Okinawan, it feels a bit funny to me as I have used English in my work for over 40 years. My children do not speak Japanese or Okinawan, but one of my granddaughters has learnt Japanese at school and went to Japan on a school tour.

Sometimes Okinawans make the trip to Thursday Island to visit their deceased relatives buried in the Japanese section of the cemetery. The Japanese Memorial at the Thursday Island cemetery is very good as families of those buried there can come and visit. 
Elizabeth Mary (Betty) Ah Boo Foster is the daughter of William Manup Ah Boo and Almira Mayor, both from Thursday Island. Betty was also born on Thursday Island in 1936 and is of Torres Strait Islander, Malakan, Javanese and Filipino heritage. She married Thomas Douglas Foster in 1956 and they had seven children.

Paula Foster was born on Thursday Island in 1970. She is the youngest of seven children. Her parents are Betty Foster née Ah Boo and Thomas Foster, who changed his surname from Farquhar. Paula is therefore of Torres Strait Islander, Filipino, Malayan, Scottish and New Zealand descent. She is married to Mark French and has a daughter and a son. She is currently working as a teacher coordinator with RATEP [Remote Area Teaching Education Program] in Napranum.

It was during World War II, in 1942, that the people living on Thursday Island were evacuated to the mainland. My mother, Betty Ah Boo, was one of the many who was evacuated south with her family. Prior to the evacuation, there was great fear among my grandparents, Almira née Mayor and Manup Ah Boo, and my great-grandparents Lass Sedan and Assan Ah Boo. Prince of Wales Island, being the largest island in the Torres Strait, seemed the most appropriate place to hide from the army. The army consisted largely of Europeans; however, Torres Strait Islanders and a mixture of Torres Strait Islanders with Malaysian, South Sea Islander and South-East Asian descendants were also enlisted. Before the enlistment there was much controversy over whether or not non-Europeans could be trusted. Hall writes, 'The conscription of non-European was barred by the Defence Act, but many Aboriginals and Torres Strait Islanders managed to enlist, particularly after Japan entered the war.' The army was responsible for ensuring that the people on Thursday Island were evacuated.

According to my mother, the two months that they lived in hiding on Prince of Wales were the most difficult months of her life. She told me of the American bombers that flew over Prince of Wales, vibrating the island and leaving everyone scared. As a child of seven, my mother, and her family, had to wake early in the mornings - about three o'clock each day — to go into the bush to hide; they would then return to their camp when it was dark. Their camp was made out of bush timber and mangrove wood. Mangrove leaves were used for the roof so that the army would not find them.

While my mother and her family were living on Prince of Wales Island their diet consisted of Sao biscuits and tinned beef with vegetables. The food 
supplies were bought from the store on Thursday Island before they moved to Prince of Wales. For water, they had three dug-out wells, which had been built by my mother's father, grandfather and uncle.

Eventually, my mother, her family and the other Malaysian families were found by the army. One of the men in the army was part-Malaysian and he had relatives living on Prince of Wales. He reported them to the officials and they were then tracked down. The reason the army gave my mother and her family as to why they had to go south was because the Japanese planes might fly over and bomb Prince of Wales Island. Five minutes were given to my grandparents, great-grandparents and the other Malaysian families to pack one small suitcase per family. In my mother's family, she had one younger brother and sister; her mother, Almira née Mayor, was pregnant with another child. After being taken over to Thursday Island in a launch by the army, my grandfather, Manup Ah Boo, was conscripted as a cook in the army. It was 26 February, 1942, when my mother and the rest of her extended family were put on the schooner, Goodwill, to be shipped to Cairns.

On their arrival in Cairns, they were put on to a train for Murgon. At each of the stations at which the train stopped, the Red Cross provided food and clothing to the evacuees. After reaching their destination at Murgon, my mother, and the rest of her extended family, as well as the Malaysian families, were loaded on to big trucks. These trucks took them inland to Cherbourg, which was to become their new home. My mother's first impression of Cherbourg was that it was a 'creepy place'.

Cherbourg had nearly 7,000 acres of land. The settlement had been formed originally by bringing together Aborigines from southern Queensland. Aborigines who were considered to be unhealthy were sent to Fraser Island Mission in 1897, from 1902 to Durundur, then later to Cherbourg. It was in 1931 that the settlement became officially known as Cherbourg. Prior to that, Cherbourg was a government settlement known as Barambah. Originally, it consisted of 2,805 hectares in two sections near Murgon and Wondai. In 1904, Barambah was a grazing property that had an economic basis in agriculture.

It was late in the night when the big trucks pulled into Cherbourg. My mother and her family were taken to a two-storey dormitory. The living conditions were cramped and overcrowded in the dormitory; there was one family to a room. The night they arrived they were given scones, syrup, black tea, unbleached sheets, grey blankets, pillows and pillow slips. No mattresses were given out. This was their temporary accommodation. My mother and her family lived in the dormitory for about three months.

In 1934, an act was amended so that the Chief Protector had the right to control any 'half-castes'. J. W. Bleakley was the Chief Protector from 1913 to 
1942, but in 1942, Mr O'Leary took over. In 1937, Bleakley had attended a conference in Canberra. The major issue that was discussed was the need to find a national view on Aborigines. The Queensland opinion was greatly different from that in the rest of Australia. This was partly because the Queensland Government also dealt with Torres Strait Islanders and part-Aborigines. Bleakley held negative views about racial mixing and intermarriages. He suggested two solutions to the situation. One of the solutions was the removal of 'quadroons' and light-coloured people from Aboriginal environments, and the other solution was to leave half-castes and darker people to be cared for by the Government. After much discussion, the conference disagreed with Bleakley and a policy of assimilation of Aborigines into European society was agreed on. In 1939, the 1897 Protection Act was replaced by the Queensland Aboriginals' Preservation and Protection Act. This new act was an extension of powers held under previous legislation and the Chief Protector was responsible for its administration.

In Cherbourg, my mother and her family had to adapt their lifestyle, which had been independent and centred on the sea, to an isolated rural lifestyle, which was dominated by the Chief Protector. The many adjustments made by my mother and her family seemed inevitable, one example being the use of coupons. The Chief Protector issued each family with a coupon booklet. Each coupon had an amount on it. Each family was allowed to get only as many goods as the coupon figure showed. The store contained food, tobacco, toiletries and clothing and the basic foods were supplied free to the people who lived at Cherbourg from a ration store. This makes it seem as though the people had an unlimited supply of food, but this was not the case as each family was restricted in what they could have by the use of coupon booklets. Another example of the restrictions that came with living at Cherbourg was the use of permits. A permit was needed if a person wanted to go off and on to a settlement. My mother told me of her friend who left the mission without permission. My mother described the girl as being 'pretty with long hair'. When her friend came back to Cherbourg, she was taken to get her head shaved. This was done so that everyone living at Cherbourg knew what the girl had done. It also showed the people that they would get the same treatment if they did what the young girl did. The permit system was established in Queensland in 1897. The 1939 act also set out the conditions of mobility. Aborigines could not leave or 'escape' without permission, nor could they go on to other settlements without permission or a removal order from somewhere else. If anyone did not comply with the rules on the reserve, he/she could be put off the reserve. Other adjustments that my mother and her family, as well as the other Malaysian families, experienced was their changing diet. Prior to the evacuation, seafood 
was the main source of protein. At Cherbourg, the main source of protein was beef. The climate was another adjustment that the people from Thursday Island experienced. Winter was a totally new experience as there is no such thing as winter on Thursday Island. According to my mother, there was not much interaction between the Aborigines living at Cherbourg and the people from Thursday Island. My mother told me that the Aborigines kept to themselves.

The accommodation at Cherbourg was insufficient. There were four types of houses there: one was the officials' house, which was occupied by the people in charge of the settlement. The other three types of houses were for the Aborigines. The first category were small shacks, which had no floor covering, no ceilings, corrugated iron for the roofs and shutters. These shacks were the oldest type of housing. The second category of housing was more recent. These were conventional three- to four-bedroom houses. The first and second category of housing suffered from poor building standards. The houses were prone to leak and to be draughty. The third category was a modern housing commission-style of home built for the community council chairman. During the time that my mother lived at Cherbourg, two to three families were forced to live together. My mother's description of the house in which she lived fits the second category of housing. My mother's family and two other Malaysian families lived in a fourbedroom house which was built out of wood from the forest.

During my mother's stay at Cherbourg, her mother gave birth to a baby boy. My great-grandmother, Lass Ah Boo, delivered the baby. There were other Malaysian ladies who also had babies at Cherbourg. At the end of the war, the birth rate at Cherbourg had overtaken the death rate. Population figures for the period 1940 to 1945 are not available but, if they were, they would perhaps have showed a decrease in population when the men from Cherbourg left to join the army and residents found work for themselves in other towns during the war years. However, perhaps the population may have increased when the people from Thursday Island were evacuated to Cherbourg in 1942.

My grandfather, Manup Ah Boo, was discharged from the war a year later in 1943. Once discharged, he went to Cherbourg to take my mother and the rest of the extended family off the reserve. My mother's family then moved to Bundaberg where my grandfather was employed as a cane-cutter. The Ah Boo family lived in Bundaberg for seven years. It was not until 1949 that the family returned to Thursday Island. The reason for returning to Thursday Island was because the family missed their home, an independent lifestyle, the seafood and their friends. My mother has not returned to Cherbourg since the day that her father took her and the rest of the family off the settlement.

My mother went to the Catholic school when she returned to Thursday Island but she only went as far as Year 3. This was equivalent to Year 7 in today's 
education. In those days, this was seen as the normal thing to do. At the age of 17, my mother was employed by the Farquhars, who owned a store on the waterfront. She met my father, Thomas Farquhar, while working in the shop. Despite family opposition, my mother and father were married five years later in 1956 on Thursday Island. After getting married, my father decided to change the family's surname to Foster as he did not want to be a part of the Farquhar family. This was done through the Courthouse. In 1959, my mother had her first child, Deborah. Deborah was the eldest of six other children who followed. After Deborah came Thomas, Stephen, Kevin, Sharron, Trevor, then myself, Paula. Before my mother retired, she worked at the same site where she was employed many years ago, although in a different building on the same waterfront. She was employed by the Aboriginal Hostels as an assistant manager in the Jumula Dubbins Hostel. My mother is now a grandmother to 24 children and has seven great-grandchildren.

Billy Isao Shibasaki is a Nisei (second generation) of Japanese and Malay/Islander origin. He married Seriba Bin Garape of Malay/Torres Strait origin in 1963. They have four children and seven grandchildren. He served as Deputy Mayor for Torres Strait Shire Council from 1997 to 2000 and as a Councillor until March 2003.

I was born in 1940 on Thursday Island. My dad was born in 1900 in Wakayama and came as a diver to Torres Strait when he was a young man. My mum was born on Horn Island and was of Malay/Islander origin. When the war broke out, I was a one-year-old baby. Dad was taken away and interned separately from us during the war. Therefore, I spent my early childhood not knowing him at all. Soon after his release from the internment camp in 1946 he visited us briefly in Bundaberg before returning to Thursday Island to continue working in the pearling industry. On his arrival in Bundaberg, I asked my mother who this man was. After my mother, brothers, sisters and I all returned to Thursday Island in 1947, we became a whole family again and re-established our close ties with our father.

Again life was unkind to my recently reunited family as my dad died from cancer three years later in 1950. By this time there were eight of us. Another sister and brother were born after the war. It was hard on Mum. Two of my older brothers had to seek employment to provide for the family. They followed in our father's footsteps and became pearl-shell divers.

My father was of average height and well-built. He promoted his country through his respect, friendliness and kindness. Before the war, my father worked as a pearl diver in the Darnley Deeps off Darnley Island and visited Yorke Island regularly. The old timers on Yorke Island still remember him well. He looked after his fellow workers well and everyone called him 'Kew'. 
When Dad was working, he was gone for months at a time and so we grew up not knowing much about our Japanese heritage. We were brought up by our Mum's culture, which was predominantly Malay, and this was greatly influenced by the fact that my grandparents were living with us and practised their culture.

I was fortunate to have visited Japan and to meet up with my uncles, aunts and cousins. The family has not established contact with any of my Malay relatives overseas. I believe that if it was financially possible other members of my family would visit with our relations in Japan.

I enjoyed my school years and continue to have fond memories of those precious years. I mixed with boys and girls of different races and religions. I loved parties and was a member of a band called the Checkers in the 1960s with my cousin, Martin, and five other young people. When I finished school, I worked in the shipping and airline industries; local hospital administration, pearling industry, and the pearl-culture industry. I became the managing director of Oceangem Pearls Pty Ltd., a joint venture company with the Kakuda Australian Pearl Co. in Japan, until the companies were taken over by Kyushu Pearl Co. Ltd. Japan. I remained with the industry until 1997.

When our father's generation was alive, they drank beer together and kept regular contact with each other, but we, the second generation, are fragmented. In the old days, there was a Japanese society and an established clubhouse. I think it would be interesting to have a society of Japanese descendants on the island. Although there is a cultural festival held biannually and was to include all cultures, the emphasis is on Torres Strait Islander culture and too little is known about the Asian heritage of a lot of the people living on Thursday Island. The new Gub Titui Gallery was built with funds allocated to the Indigenous people of the Torres Strait and therefore will showcase only Aboriginal and Torres Strait Islander arts and crafts. But I also think it's vitally important that our Asian cultural heritage be preserved.

Mahendra Mendis was born in Brisbane in 1949, the son of Nissanka and Amara Mendis and grandson of Punchi Hewa Mendis, a Sri Lankan business pioneer in Torres Strait. He grew up on Thursday Island before attending boarding school in Ravenshoe on the Atherton Tableland. Returning to Thursday Island, he joined the Queensland Department of Aboriginal and Islander Affairs and later worked for Comalco for 25 years. After his father's death in 1989, he and his mother went to live in Victoria Point, near Brisbane. Mahendra now works for Blue Care, Brisbane South Region. 
I was born in Brisbane, but we went up to Thursday Island on the Elsanna when I was about six months old. Grandad had a business there and Mum and Dad helped him out. We were down near the Customs House in those days, across from the Post Office: there was a building on the opposite side of the bank, the same block as the Customs House but on the other end of it. The Customs House is on the water end, on the main street there, and there was a long building where Mum and Dad and Grandad used to sort shell.

Grandad was a big influence on my early life. He came to Thursday Island in 1898, but Mum and Dad didn't come until after the war in 1947. Grandad had gone back to get married

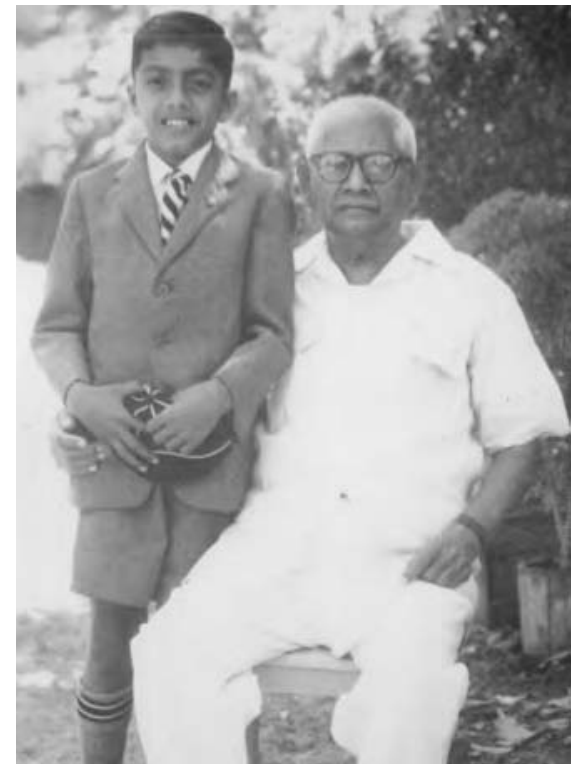

Punchi Hewa Mendis and his grandson, Mahendra Mendis, c.1950s. Courtesy of Mahendra Mendis. and he had two children in Sri Lanka.

The eldest one, my uncle, came out before the war, but my Dad stayed in Sri Lanka. Afterwards, the other brother got married as well and they all came out together and lived in Brisbane for a while. My Dad stayed on here, but later Grandad wanted someone to look after him and he asked Mum if she would. They went up to Thursday Island just after the war, when they were rebuilding Thursday Island and Grandad was re-establishing the business.

Grandad got into pearling a while before, in the early 1900s. He began as a printer's assistant and then he had a little general store and he worked in a pub for a long time. People say he never drank alcohol, didn't smoke or anything like that. A lot of the older people said that he was probably the smartest of the lot, because he saved his money, whereas everyone else was busy working hard to collect money and then spent it gambling and drinking. Thursday Island was known for that in those early days.

The key to his success was a pearl. He had become pretty knowledgeable about pearls and he bought this one for about $£ 40$, a lot of money at the time, with the bank manager's help. The bank manager, as far as we can gather, knew Grandad pretty well. Grandad had made an arrangement with the travellers who sold watches: he used to take a few watches and he'd say, 'Look, I'll sell them and give you the money when you come back.' His employer at the hotel told the travellers he was trustworthy. Grandad always came good and he gained 
a good reputation. Going up and asking the bank manager for $£ 40$, it was a lot of money, but the bank manager trusted him. At that time you had to send pearls to London and a very long time later he got back a cheque for $£ 600$. That's what started him off on his own and he went and established a pearling company. He had several luggers and was the first to send trochus shell to Japan. He also sent Sunshine milk to Sri Lanka.

My grandfather had relatives in Japan and Singapore, even as far away as the US. They came from Galle: it's a fishing port, so a lot of ships used to come through and they used to catch a ship from there and they'd go. It was part of the British Empire at that time and a lot of people went to Singapore also. My grandfather wasn't a jeweller by profession, but on Mum's side they were jewellers and a lot of the other families that went to Singapore became jewellers; whether they were jewellers before or learned the trade there, I'm not sure.

My earliest memories of Thursday Island are that there were a lot of transient people, very different types of people, people from all over the place and travellers who kept going and coming. It was a real port of call and they'd come to the shop to buy a paper. We were lucky, we'd see a lot of people. Mum, especially, kept in touch with a lot of people: in those early years she knew hundreds of people. Grandad was pretty shrewd and he developed things all the way through that period. He went from where we were first, moved to another shop and bought a few other places, but he was very discreet.

Nothing was on paper. I remember a lot of transactions were just a handshake. No one ever knew how that transaction was handled, just the two people involved. It was amazing that so many big things were completed that way. Obviously, you have to trust the person in order to lend, for example, startup capital for a business. But money changing hands, you wouldn't have any idea of what was going on if you weren't directly involved. We've lost that trust in people today. Grandad tried to help a lot of people all the way through, but some of them didn't do very well by him, family members who got their first opportunity from him.

I've met a few uncles who were with him during the war. When they evacuated Thursday Island, Grandad had to go somewhere else, so he went to Darwin and opened up a business there. He built a new shop and he stayed right up until the bombings, because it was difficult getting out of Darwin: the older people and the women and children were flown out first. His eldest son was with him and a cook and another relative, members of his extended family, were working in the shop, selling things to the troops. During that period, even when Grandad was there, they were selling magazines and jewellery and all sorts of strange things. They could never get rid of the soldiers out of the shop in the evening. The soldiers just kept coming in and buying things because there was 
no competition, apart from a few Chinese people who they knew pretty well. So the old cook used to get a pan and put chilli in it and then fry it. People couldn't stand those fumes so they'd leave and then they could lock the door and go to bed.

When we went to Thursday Island we lived with my grandfather. We moved from one shop in the main street to another shop he had built and we lived on top and built another extension out. That's where Col Jones is now. He's built his shop right across the whole of that area, whereas we just had that bit on the top and at the side and a big yard at the back. That yard with the big mango tree was my playground. Alan Taylor lived next door with his mother, Auntie Kay. Her mother was Mrs Jenap, Auntie Jenap. She made the best long soup on the island and they all used to go with little billies to collect it. She made the noodles herself.

There were some really wonderful people around us: Uncle Connie and Auntie Lullie Filewood, Uncle Dan and Auntie Bulla McGrath, Mr and Mrs Bintahel and Calammi Pilot. The kids we knocked around with were Alan Taylor and there was Vic, Carol and Larry McGrath at the back and then down the street and across the road there was Bruce, Alan and Neil Filewood and then across the back of that were the Bintahals, Toby and all those, and then there was Philip Mosley. The Mosleys used to run the Grand Hotel. And down a little bit further from us was Teddy Abednego and then Richard Barba, who was on the main street as well and lived with Dato Jia, Auntie Jenap's brother. That was our gang: a good mix of people. Vic took me and Carol to school on my first day. I don't remember, but they tell me that I couldn't speak a word of English. We had just come back from Sri Lanka after a year away, when Dad thought we might go back and live there. I don't know how we all got through that.

There weren't so many Torres Strait Islanders on Thursday Island then, although there were a fair few around the back of the island in Tamwoy Town. I remember the buildings were old and dilapidated, but the whole area was always very clean and the area around the houses was carefully swept. We would wander along the ridge of hills down to the fort, but the cemetery was a taboo area. The main thing to remember about that time is that it didn't matter where we went or who we were with, all the adults were like our real parents in that they wouldn't allow us to do certain things: we were reprimanded for things wherever we went. You were always on your best behaviour when you were around adults. They all seemed to have the same ideas about being strict.

At an early age, I was very conscious that we had money but a lot of people didn't. But I don't ever remember an instance where that was brought up. If you went to someone's place, you had a drink and a biscuit or whatever 
was going. If it was lunchtime, they'd make you lunch. No one ran home or rang up or said, 'They're down here'. You had to be home by five o'clock in the evening and that was the only stipulation. Most times people knew where we were. I suppose we must have had some sort of routine about where we were or what we were doing. There was an old Malay man called Rompong. He was retired by then and lived next door to us in the boarding house with Mrs Jenap and Auntie Kay. He was the loveliest man, our guardian angel, wherever we went, he was always not far behind. You would never see him, but he'd pop up out of the blue and herd us up at 5pm, saying, 'Bath-time, bath-time, boys.'

We had a marvellous life. I never felt unsafe. We used to wander off down to Jumula Dubbins' place down the end of John Street. It was a huge house near the Post Office, part of Yokohama and she had five rooms for boarders. In front of her place was the road that went past See Hop's and out towards Hocking Point. We would cross the road and go swimming on those wonderful days when the tides were high and the water was perfectly clear and warm. You could see the white sand at the bottom. We would play for hours. Auntie Jummie had a little shed out the back with a shower. She would make us all have a shower, dress us, feed us and send us home for our afternoon nap. Auntie Jummie was very influential in my life. There was always wonderful music coming from her place. Her daughters, Auntie Lullie and Auntie Bulla, played the piano and they and Auntie Joy and the boarders sang all the old songs.

We would always get into trouble for not wearing shoes. We used to get out the back and just take our shoes off. We'd usually leave them there and then pick them up on the way home. We kids used to wander everywhere. We'd get a nail in the foot probably about once a week. Once, when we were cleaning bottles to sell to the soft-drink factory, I got a roofing nail in my foot. An old Islander man came out of the factory and got it out of my foot. He then took a weed, a little bush, that used to grow there and squeezed the leaves into his hands, rubbed them on the wound, tapped it with a small stick and in a couple of days I didn't even have a sore.

When I was about seven, I used to creep out on the roof overlooking Douglas Street and watch the fight every Saturday night between the halfcastes and another group. It usually began in front of Wally Woods' place. A lot of people would remember Wally: he made water tanks and married one of the Saranealis sisters. There was a streetlight just in front of his house. I don't know if they were Aboriginal or Islander people, it's a bit hazy. Someone would call the police and everyone melted away into the night.

I last went up in 1989 and it's become a completely different type of place. It seems that people are still divided, but differently from the way it used to be. It's the same divide but it's the Europeans taking the back seat. The major 
difference is that now everyone can have a say and express their views and it'll be in the papers. When I was growing up, it was very much suppressed. People saw things and were very upset about them, but they wouldn't have brought it up. Ted Loban used to rock the boat and many people disliked him for it, although they secretly agreed with him.

I think the younger group don't have the same fun as we used to. In the 1950s and 1960s, there was a vibrant musical scene. People really enjoyed making music in their homes and there were great bands that played at dances and at parties in people's backyards. Every time the Elsanna was in port, its band would play at the Town Hall dances, mainly dance and jazz music with piano and violins and occasionally you could go and hear visiting musicians. That was when Seaman Dan, George Dewis, Jerry Lewin and Billy Shibasaki had a band. I remember Karim Binawel was a great guitarist. The music changed in the 1960s, when everyone could go to pubs. With the pub scene, the music changed to rock'n'roll and more guitar playing. The See Kee brothers played well and Riti Doolah was the leader of one group. Vic and Larry McGrath and the Galea brothers played in a band called the Hungry Eyes, which was excellent. They all played by ear. Fun now is associated with drinking, whereas fun in those days was associated with music and dancing. People probably drank when they went out, but you didn't see drunk people.

When I was growing up, distance wasn't a problem. You walked everywhere. That's another big difference: all the cars in the street and the safety factor. Another change is in the structure of the town: there were far more old things then - houses, shops, sheds - but now you've got very modern buildings. The other main difference is in the schools, which used to be segregated. We went to the school on the hill, but that was European and halfcaste. There was another school that was all Torres Strait Islanders.

I went away to boarding school and my best friends there were from Thursday Island, Peter Ahloy and Allan Samuel. After I came back, I believed very strongly that it was good to go away to school. I wish they'd all come away with me, I just thought they would have been a lot better off.

I went to work for the department after I finished high school and one of my jobs was to help people get government pensions. What struck me was how many people didn't want pensions. They were living on the basics but they were happy with what they had. I had to convince them to apply. Those old people were extremely kind and generous and I admired them very much. Some of them helped me a lot, people like Arthur Ahmat, Abigail Bann, Lui Bon, Elsie Harry, Mrs Daisy Laifoo, Dato Frank Mills and Tanu Nona. Some of my coworkers were absolutely brilliant, but where's the opportunity? Robert Mye was the most brilliant person I've ever worked with. He had a fund of local 
knowledge and a photographic memory. He could remember every case, what file and even what page something was on.

That's why I think the Islanders should be educated not only in their own culture, but in the way other people deal with things. You can't just ignore that, because there could be better solutions to problems. Torres Strait is an isolated place and it's easy to be isolated, so Islanders need to be self-sufficient in some way, find some economic niche. There's a lot of talk, but not enough action. There are good leaders, people who are trying to make changes, but it takes time.

I think we have to have some autonomy. It's a bit like Singapore, it needs strong leadership to bring everyone together and get everyone working in the same direction. Nowadays you see some of the things that come out of Torres Strait and there's no comparison with before. For instance, they used to make things out of shell that were absolutely brilliant. You can't get things of that quality now. They have some of the best musicians and sportspeople in the whole world. If you had 15 famous Torres Strait Islanders, they could raise millions of dollars and really get things going.

\begin{abstract}
Martin Nakata is Visiting Professor at Jumbunna Indigenous House of Learning at the University of Technology, Sydney. Of Torres Strait Islander, Japanese and Samoan descent, he was born on Thursday Island after the war and is married with two daughters. His 'voice' is adapted from an article he first published in 1995 in Re Publica 2, pp. 61-74, entitled 'Better', and it is reproduced here with his kind permission.
\end{abstract}

My father is Japanese and was, in my early years, a pearl diver. My mother is a Torres Strait Islander who grew up on Naghir Island in the central Torres Strait region. Her grandfather was a prosperous and enterprising Samoan. When he died early this century, his assets, including $£ 10,000$, were left to his family. We never saw it. It was irrecoverable, lost in the maze of so-called 'protection' offered by the Department of Native Affairs or whatever it was called at the time. The family, of course, felt that they had been robbed, but weren't quite sure how it was done. For my mother's father, who became the chief of Naghir Island, and who was my grandfather and an influence on me throughout my life, education - White man's education and knowledge and languages, that is became a matter of great importance. Education was needed not just for economic development, but also to understand and know the White man well so he could not rob us again. We needed to understand how it was that they did things that seemed to advantage them but not us. To put my grandfather's 
thoughts into political terms, he believed that to negotiate our position in the islands we needed the White man's languages. To put it simply, he wanted an insider's view of the White world. I don't want anyone to think I grew up in a family that was openly hostile to the White world. I grew up watching this Christian hospitality benefiting everyone except us.

Because my grandfather was so keen for his children, including his daughters, to receive the best education, my mother and her twin sister were sent away at the age of seven to board at the convent school on Thursday Island. This was in the mid-Thirties, well before citizenship and well before any Commonwealth funding. My mother learnt to read and write and do basic maths and received an education to Year 4 level. And, of course, she also learnt to boil up the nuns' habits and linen in the copper, to mend, starch, iron and scrub, to prepare food, to wait on priests at tables, to garden and to milk goats. As a teenager, she became, without any training, the teacher at the small school on Naghir Island and remained there until her marriage in the early Fifties. This school, one of the first primary schools in the strait, had been conceived, built and paid for by her grandfather in 1904, and had been staffed at various times by the Department of Public Instruction.

So, you see, we weren't exactly sitting under coconut trees waiting for handouts.

In 1964, my grandfather made the momentous decision to abandon his island. Anyone who understands the attachment we have for land, sea and way of life could perhaps understand the incredible pain and pressure my grandfather had to confront. But the fact was that the war changed a lot for Torres Strait Islanders, and the economic and educational opportunities were much better on Thursday Island. It was the younger generation - my generation - about whom he was concerned. Whenever I'm struggling with my academic work, I often think of my grandfather. I think of his generous nature, and his bitterness and suppressed anger and confusion over the intrusions of White control into his community. I think of his efforts to build on his own father's perceptions, that a White man's language and education would give us equal passage in the world, and the aspirations he held for his children. And I think of the hopes he had for all his grandchildren that we could do 'better'. And his sadness towards the end of his life when he realised that despite some successes, despite the fact that, yes, things had changed and that we were able to go away to school in the south, that we had 'more' education and some of us eventually made it to tertiary level, that relative to Whites, we were not really in a much better position than we had been all those years ago. His biggest sadness, though, was due to the doubts he had about giving up his island for this other dream. And what for? 
My own education occurred mainly on Thursday Island, from the early Sixties to the early Seventies. This was well before any 'special' programs became available to us. We had the straight Queensland curriculum, taught by White teachers who had no special preparation, who probably didn't know we existed until they found out they had a transfer to the region. There was no recognition that English wasn't our language. In those days, I think, Torres Strait Creole, our local language, was not considered to be one, but rather broken, bad English instead. I learnt to read on Dick and Dora. I started off at the same convent school my mother went to, which is still there today. My father took us out of there, after arguing with the priest about how much of school time was spent building the stone wall at the back of the church. I then went to the state primary school and I did pretty well by the teacher's standards, though I never understood anything much. But I did learn to read and compute in a basic sort of way. To this end, he'd always speak English to us and encourage us to speak and read it. All my Japanese has been learnt, not from my own father, but from other Japanese people since.

We were continually exhorted by our parents to do 'better'. My memories of school are always of trying, trying, trying, of never getting it quite right, of never knowing what it was that I didn't quite get right, of never being able to make myself understood, of always knowing that I wasn't understood. (These feelings persist, even today, even when I'm with the people I know, who are close to me and care. That frustration I felt in the primary school classroom I still feel on a daily basis in the university, even though I have proved myself in the White world, even though I have a first-class Honours degree and am doing doctoral research.)

I did badly in high school, hindered as I was by my 'bad' attitude — I was so pissed off by now with school and learning and teachers - and I had to repeat Year 10. I did much better the second time and, when well-meaning teachers wanted to take me to boarding school in Maroochydore, on the Australian mainland, as there was no schooling beyond Year 10 in the Torres Strait, my parents, who always wanted the best for me, thought that this was a good opportunity. I attended two schools in that year - I ran away from the first. Again, I understood nothing in the classroom. I understood nothing of what the teacher was teaching. I understood nothing of what we were required to read nor why. I did learn to build fences, to fix broken-down garages, to change nappies and so on. 'Homesickness' they called it, that's all. I ran away from my caretakers and made it to Brisbane, to relatives who helped me get home. My father would not let me give up school and I was sent the next term to the Christian Brothers school in Yeppoon. This was probably the time when I first took up sports as a survival strategy, but I still understood little of what 
went on in the classroom and, by the end of Year 11, I gave school away for good. I did various jobs - packing shelves, driving trucks and forklifts for a food storage company, fixing small engines for another joint and, later on, some clerical work with an agency for Ansett. With each change of job, I was trying to 'better' myself. At school, I'd wanted to be an architect. I wasn't without aspirations and I didn't need a role model to dream.

In 1980, I joined the Commonwealth Government as a travel officer, moving all the boarding school students from the strait and Cape York to southern mainland schools and back. In 1986, I moved back to Thursday Island as an Education Officer for the Commonwealth Government. It was in this position that I really began to think seriously about studying. The job ordinarily required teaching qualifications, but I had got it on account of my local knowledge. Part of the job involved liaising with teachers in the high school, and with students who were experiencing difficulties in their schooling. After all, I knew a lot about experiencing difficulties in schools. About a year later, it became obvious to me that my input was discounted at all turns, that I was there primarily as an avenue for the funding that came with the job; my local knowledge and understanding of Islander students in classrooms counted for nothing — that is, the 'Torres Strait' component of my job was merely a token.

I began to wonder whether, with qualifications equal to the teachers', I wouldn't be able to do my job much more effectively and be able to push the Torres Strait Islander perspective more insistently. So, having unsuccessfully completed Year 11, having read nothing apart from the prescribed Shakespeare and Dickens (which I never understood a word of) and local newspapers and a few adventure novels, I applied to James Cook University in north Queensland for entry into the Bachelor of Education program as a mature-age student.

When I started studying, I had to read everything at least five times before I could understand a word, and I had to keep a dictionary with me at all times. Writing was the same. I could never be sure whether I'd written a sentence or not. I couldn't believe that there was so much to know. It was a real struggle, but it gradually became easier and, for the first time in my life, I felt that I was making sense of stuff, that I was learning and that I was going to be able to do it. I was also learning to write what I wanted to say and, although it was a difficult and frustrating process, I began to feel excited about what I was doing and very stimulated to learn more and I worked pretty hard.

At this time, my eldest child was learning to read and I was also truly amazed by this process. I was very keen for my girls to do well (we're into the fourth generation now where English and education are to be our salvation) and I was often disappointed with my wife because she never seemed to me to be pursuing this cause very keenly. She'd read to them and talk to them, but 
I wanted to see them taught. You know? The alphabet and things? And she would say, 'No, no, don't worry, these children will read.' And, do you know, to my amazement, they did. It was a time of great excitement for me to witness the ease with which my children were inserted into the world of print and texts, which has resulted in their success at school.

I did begin to believe, in my second year, that what we really needed was a revolution. I was thinking more deeply about issues in cross-cultural education and I was beginning to feel a sense of dissatisfaction and impatience with some of the stuff I was reading. But I met a lecturer who has had a big impact on my life. This guy, a guy of colour, gave me something that no one else had ever given me in all of my schooling years. For the first time in my life, another person (an authority-type person) responded to me as if I was a capable, knowing person, as if I was a person who didn't have to be put on probation before I was allowed to proceed as mainstream people did. It is a hard thing to explain. Perhaps it is a thing that only people of colour can truly understand, I wouldn't know. I don't think it was so much because he took down a barrier for me. I think that he just didn't put one up. On the basis of my work, he enrolled me in an Honours program, because by this time I was sure that I wanted to go on and research rather than go into a classroom or return to my former job.

It was also about this time, in the second year of studies, that I began to feel uneasy whenever I read about people 'in the margins' — a strange sensation you get when you read about what is supposed to be a representation of yourself in a text. It can give you a sick feeling when you're thinking, 'But this isn't me' or, 'This isn't how I perceive my position' or, 'This wasn't my experience'. And then comes the related anxiety, of course: 'Is this how others see me?' 'How do others see me?' 'And all Torres Strait Islanders?'

Well, from my reading of the literature, the others see lots of things. But, overwhelmingly, I think, they see a group of people who 'lack'. Along with Aboriginal people, Islanders have probably at some stage or other been represented as having lacked everything there is to have. If the experts have named it, then we lack it. We have, at various times, lacked intellect, language and education. We have lacked control over alcohol, finances, land and sea. We have lacked as fathers and mothers. We have lacked as children. We have lacked as students. We have lacked so-called mainstream experiences. This was first noted and written about the time of the first anthropological expedition by Haddon in the 1890s and, more than 100 years later, Western experts can still name it and write it, and so we still lack it. Let me simply ask: from whose point of view are these 'lacks' inscribed on us? 
Lynda Ah Mat is the daughter of Phyllis Ah Mat from Thursday Island, of Indian, Indonesian, Torres Strait Islander and Aboriginal descent, and Gary See Kee, of Chinese, Filipino and Welsh descent. She was born in Brisbane in 1964 and educated in Thursday Island and Cairns. She now lives permanently in Cairns and is Manager, Indigenous Studies Product Development Unit, Tropical North Queensland TAFE. She has a daughter, Shari, aged 13.

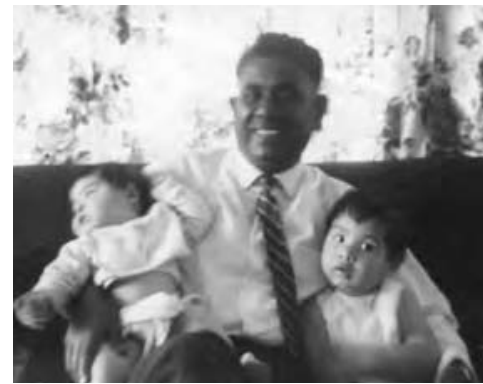

Lynda Ah Mat with brother, Gary See Kee, and grandfather, Arthur Ah Mat, Thursday Island c. 1965. Courtesy of Lynda Ah Mat.

I was born in Brisbane as Linda Marjorie See Kee to Phyllis May Ah Mat and Gary Robert See Kee, both from Thursday Island. My parents eloped to Brisbane but, as my mother was under-age, she needed her parents' consent, which they agreed to in a letter. Soon afterwards my eldest brother, Gary, was born on 11 April, 1963, on my grandad's birthday - Arthur Ah Mat — and I was born on 2 May, 1964. Gary and myself are the eldest boy and girl grandchildren of the Ah Mat and See Kee families of Thursday Island. My mother Phyllis is the second-eldest of nine children born to Arthur Usop Ah Mat and Emily Marjorie née Agale, seven girls and two boys: Marie (Brown), Phyllis (Gosney), Daisy (Ah Mat), Jacqueline (Backhouse), Michael, Frances (Visini), Sharon (Lediott), James and Veronica (Keane).

My maternal grandfather, Arthur Usop Ah Mat, was born on Thursday Island on 11 April, 1917, and died there on 29 May, 1979, the eldest son of eight children born to Amcia Usop and Ah Mat India. His siblings are Mercia, Petrie, Paul, Joseph, Julie, Portia and Francesca. My grandfather's father was known as Ah Mat India and he first came to TI as an ice-cream hawker. He was born in Delhi, India, the son of Mohama and Lacho. Ah Mat married Amcia Usop, born on Thursday Island. Amcia was the eldest of three sisters, the other two being Barria and Napsia, daughters of Moona and Ussup Sulu. Amcia's mother, Moona, was a full-blood Aborigine born at Batavia River (now known as Mapoon near Weipa). Amcia's father, Ussup Sulu, was born in Sandakan, Malay Archipelago. I believe he came to Torres Strait on a boat to fish for bêche-de-mer and pearl shell.

My maternal grandmother, Emily Marjorie Ah Mat née Agale, was born on Thursday Island on 9 November, 1919 to Gana Fred Agale of Murray Island (Mer) and Felecia née Ah Boo of Mabiuag Island. My grandmother is the third- 
eldest child, and her siblings are Uncle Maurice; Edna May, known to me as Aunty Nena (whose first marriage was to Raymond Arabena and her second to Michelangelo Lanzafame); Pauline Rose, known to me as Aunty Polly (who married Frank Romano); and Elsie Williams (traditionally adopted, who married Carl Smith). All the children spoke their traditional language, Meriam Mir. My grandmother is the only one of her siblings still alive. Nena, Emily and Polly were recognised back then as the 'princesses of Murray Island' as they are descendants of Harry Buziri, the 'Mamoose' (traditional leader) of Murray Island of that era.

My father, Gary Robert See Kee, was one of eight children of Arthur Tsing See Kee, born in Cooktown, and Linda nee Laifoo, born on Thursday Island. Their children include Arthur Richard, Karl, Anthony, Gary, Shirley, Francis, John and Winston. Arthur Tsing was the child of Tsing See Kee, born in Hong Kong, and Mary Espanies Ga, born on TI. Mary Espanies Ga was the daughter of Carlos Ga from Finagat, the Philippines, and Mary Anne née Bunyan from Caermarthenshire, Wales. Linda See Kee née Laifoo was the daughter of Laifoo from Canton, China, and Mary from Hong Kong. Linda's siblings were George, Stanley, Harry, Claudie, Sidney, Mabel, Bonnie and Nellie, all from Thursday Island.

I can't tell you much more about the See Kee family. I knew very little about them because my parents' marriage broke down when I was quite young. Looking back at it now, it seems to be an interracial issue possibly of that era, maybe even a status thing — who knows? — as soon afterwards my father's two older brothers, Karl and Arthur Richard, were sent to China to bring back Chinese wives. When I was about five or six, my parents' relationship was on and off and we moved back and forward from my Ah Mat grandparents' residence to my father and to Cairns and back.

My family moved to Cairns from Brisbane and I started school in Cairns at the Balaclava State School. My parents were still together and about Grade 2 or 3 my mother, brother and myself moved back to TI on a prawn trawler, the Kuzi, owned by Snowy Whittaker, to help my mother save money. This was about 1972. We moved into my grandparents' home on TI, located below the old high school in Hargrave Street. Our extended family lived there: as well as my grandparents were Dato Peter, Uncle Purrie, a couple of my mother's younger sisters and a brother still at home, and my first cousins, the children of my mother's eldest sister, Aunty Marie, who resided in Cairns. The rest of the family would come back and forward to visit and it was kind of cool to have so many aunties and uncles around and cousins to play with. Our family set up one area with curtains to make a room, as my grandparents not only had their own families but also from time to time took in other people in need of a place to stay, including Guru and Jimmy Baira. 
My father followed my mother back and they tried to make things work again, moving us out to live with him at the back of Richard See Kee's shop, opposite the Post Office on Douglas Street. They owned two duplexes in the back area, making us neighbours to Karly See Kee and his family. This arrangement didn't last for very long and we were soon back living with my grandparents.

We come from a Catholic family background and my mother and her siblings went to Our Lady of the Sacred Heart convent school. Apparently, it used to be a Catholic dormitory for orphans and others who needed to live there to attend school. It is the same school that my brother and I attended through to Grade 7. In those days, 'the cane' was the most popular form of discipline used by the nuns who taught us.

My grandfather was the head of the house, an honest, hardworking man with a very cheerful disposition. His beautiful dark skin always shone from head to toe with coconut oil and he always dressed appropriately according to the occasion; a proud man, very well spoken and a very strict man. On a number of occasions I have seen him wipe a cousin's mouth with fresh chilli straight off the tree if he caught him speaking back disrespectfully or swearing; and making another cousin smoke a whole packet of cigarettes until he or she was physically ill if caught smoking in or behind the toilet situated about 30 metres down the backyard of the house; or even punishing a cousin for not having a shower of a morning in the outside bathroom, which had no hot water.

My grandfather was known as one of the best fishermen in his time and everyone who could was taught to catch, clean, gut and fillet fish from an early age. I was told my grandfather was also a good boxer, a practice the local men followed on TI in the early days to win money, while most of the women played cards, also for money. He was also the secretary for the Waterside Workers' Federation and went to meetings down south from time to time bringing us back lots of Chinese goodies like salty plums, preserved mangoes, plums and kunji mangoes to save us buying them at the local stores. He would also bring back lots of Chinese delicacies, as he loved to cook a mixture of Asian foods including Indian, Japanese, Chinese and Malaysian foods. He was the best cook that I know of. He was always entertaining his friends with his cooking, even though we only had a wood stove. His children, the youngest two close in age to my brother and I - Aunty Bonnie and Uncle Jimmy - and all us grandchildren and cousins learnt to sing and dance from an early age to entertain him and his guests. We were a very musical family: four out of my mother's seven sisters could play the piano and guitar or ukulele and both brothers played the guitar; all could sing and all the girls, including us grandchildren, could hula. 
Christmas time was the best. We would all help with the food preparation and all the kids would get to chase the chosen nanny goat - the one that was fattened up especially all year round for my grandfather's famous curry around the house and up the hill. Then we would help catch the chooks that we fed and grew from chicks. My grandmother would have the big outside boiler on, she would chop their heads off with one blow, dip them in the boiling water and let us pluck them. My grandfather and the other men, including Uncle Dewi, Guru, Uncle Jim, would prepare the pig: first the warm blood from the pig was congealed to make a popular Torres Strait dish called dinagwan, then the rest of the pig was prepared for other dishes.

My grandfather used to make all of us go to church every Sunday, even though he didn't go himself. There would be lots of us, because our family and all my cousins lived in the one house, so we all marched up the hill past Laifoo's and Takai's and down the hill to the Catholic Church on a Sunday night. When we got home he use to line us all up and ask us, 'Who's the Lord and Raja?' We would all sing out, either 'You, Dad' or 'You, Grandad' and he would reward us with chips and soft drinks. I think it gave us incentive to go to church on Sundays when we were feeling slack. The day sermon was no good to us, as my grandparents had land down at Long Beach on Prince of Wales and we used to load up the Jacqueline (named after Aunty Jacqui), my grandfather's putt-putt motorboat and go camping most weekends. We had chores to do before we could play, swim and go up the rocks to fish and collect sea snails and crack oysters. We used to help clear and clean the land, plant coconut trees and other fruit and vegetable trees, drag for mullet; then if we were lucky, fish off the rocks for bilas using periwinkle for bait, and crack heaps of oysters and collect periwinkles and cats-eyes to take back to camp to throw on the fire or boil in a billy can to eat. My grandmother would carry heaps of safety pins so that we could all pick out the sea snail meat from the periwinkles and cats-eyes. It was not only good fun but very tasty. The men would get deer and sometimes dugong or turtle and, if it was the 'turtle fast' season, we would go round Prince of Wales looking for turtle tracks to dig up turtle eggs that were best eaten on hot rice with soya sauce. That is only some of the sea food we use to catch and eat. My grandfather taught us well and made sure we all could gather food to feed ourselves. We ate like kings and queens: no one young or old was ever deprived of good food.

I grew up as Linda Marjorie See Kee, not Lynda Marjorie Ah Mat. Linda was the first name of my father's mother and Marjorie the second name of my mother's mother. My brother, Gary Robert, was named after my father, Gary Robert See Kee. After my parents split up, we had nothing to do with the See Kees: we never spoke to any of them and we didn't go into any of their shops; 
there seemed to be too much tension. We'd walk past the shops and go to See Hops, Laifoos and Peddells or Col Jones instead, we would not even look sideways at them. I used to always wonder what people thought: the old lady, Linda See Kee, used to sit outside her main shop and see us walk past and she would just stare. There was no conversation, there was no 'hullo' and we weren't game enough to look anyway. That's how we grew up. On the odd occasion our father used to deliver prawn baskets of Easter eggs to the school and tell them to give it to us - once he even brought bicycles - and that's how we would get things from him, not that we accepted any of it that I can remember. My mother was very strict and she taught us to make do with what we had and we learnt to work and support each other from an early age. Both my brother and I were responsible for many chores: we could cook and clean and had set chores every day. I learnt to cook rice and fry sausages, fish and eggs and iron clothes from the age of eight. Now I love cooking and cook without recipe books or measuring utensils. I can practically cook with my eyes closed, even on an open fire.

So, by the time I grew up, became a hairdresser and came back to TI and had my own hairdressing salon, I took it upon myself to change my name. I felt honoured to make the decision to change my name to Lynda (with a ' $y$ ') Marjorie Ah Mat, as I didn't feel like I was a See Kee. I knew as little about them as they knew about me and it didn't seem right to open a business where the majority of businesses were either See Kees or Laifoos; plus the struggles my mother, my brother and myself experienced made us closer and we stuck together through thick and thin. All my family and cultural values came from my Ah Mat upbringing and I felt that my mother and her family deserved the recognition and credit for bringing me up the way they did. My mother struggled to give us what we needed to become respectable, honest, hardworking, proud adults today. She worked very hard and got no support outside of her own family and in those days there was no such thing as child maintenance. My mother was just like her parents, strong, proud and strict but with a friendly disposition. She was a people's person like her father and also very much like her own mother, loyal, hardworking, a proud woman who gave all for her children. My grandmother at the age of 84 is still living on TI, still very strong and a hard worker, beautiful and regal.

My mother was taken out of school at the age of 15 to help my grandfather put food on the table for the rest of the family. She started out working as a cleaner for the Four Winds owned by Jim and Ivy Cadzow. She did odd jobs including cleaning, scrubbing, cooking and ironing for five pounds 10 shillings a week, which went straight to my grandfather. At night, she had a part-time job babysitting for the Mosleys, who then owned the Grand Hotel. 
She also waitressed at the Royal Hotel, before moving on to a hospital job, where she started out filling in for the X-ray nurse, working in the medicine dispensary and pathology. She left home to marry, but on her return to TI in the early 1970s, she again picked up her job in the pathology, where she stayed until we left in 1978.

My mother found happiness once again in her marriage to John Gosney and soon came my youngest brother, Lyndon, born in 1974. I had a new father figure: he has been our dad ever since and still is. It was a huge change for me but I managed to cope, and so did my brother. In 1976, my mother sent my eldest brother to an all-boys' boarding school in Cairns, St Augustine's, but I continued my schooling on TI to be closely watched. You know, being a girl and all, I was there to help my mother. We stayed on TI up until about Grade 9 and then my family decided to move to Cairns in 1978, where I continued my education at St Monica's Girls' College. Sadly, my grandfather passed away in 1979 and we went back for his tombstone opening in 1981 or 1982.

Both my brother and I spoke Broken English, as did all the local kids on TI, but the adults in the family didn't always agree with it. I'm glad that I can speak and understand the basics, as I feel I have an advantage over those kids who weren't allowed to speak it. We used to play with our friends in the neighbourhood and speak it anyway behind our elders' backs and, before you knew it, no one sounded any different in the neighbourhood or at school. My parents and my grandmother would always tell us, 'Speak English!' when we talked Broken among ourselves. My grandmother could speak the proper Meriam Mir traditional language fluently. I really would have liked to have learnt it but she never taught any of her children to speak her language, apart from a few words here and there. She tells me the language they speak out at Mer now is not the true language she was brought up with. She used to tell me that at school on Murray Island they made them speak English, but when she went home she would speak her own language. She feels that everyone benefited from learning to speak English and I agree with her now that I'm older, but I still think it is also beneficial to preserve her traditional language. She never taught it to any of her children and I don't believe it is still as strong as it used to be: my grandmother believes it is broken down with Torres Strait Creole. My grandmother always praised the Coming of the Light, as she believes this was a good thing for the Torres Strait, teaching the people to wear clothes and speak English, the White man way.

Now I'm more aware of how and maybe why my grandparents thought the way they did. My grandmother was raised on Murray Island and her way of thinking was a little bit different, old fashioned to today's generation. She didn't agree with wearing togs, or showing too much of the body. She believed a 
woman's place was in the home learning to cook and clean first, before going out styling up for man. My grandfather was born on TI and his background was Indian, but he had a really different outlook on life. He associated mainly with the Europeans. He did have his Malay friends and Chinese friends, like Uncle Putt Ahmat down the road, Uncle Ali Drummond, Uncle Tommy Fujii and many more - they would exchange food and recipes continually and stuff like that.

Both my grandparents seemed to want their girls to marry White men, to have a better life. So the way of thinking back then was quite different to what you find now. In that era, if a mixed-race or light-skinned girl was dating an island boy, there was always talk in the house, for example, 'Oh, what them pla bunging on, going out with all ailan boy, all no shame, all come from good family?' These sorts of comments were common throughout my upbringing and most of my mother's sisters and my mother in her second marriage actually did marry White men. That was the era I grew up in, although by the time I was in high school lots of my friends were rebelling and going out with whoever they wanted to, regardless of what was being said around town.

In my days there, TI seemed to be made up of many divisions and many mixed races across both TI and Hammond Island. I guess being a part of the Catholic Church and school and hanging out at the close-knit community functions you tended to have more to do with what was known in those days as 'half-caste' people. Although a derogatory term today, it is still mostly used by the older generation when trying to explain the light-skinned or mixed-race Torres Strait Islanders. For example, the Hammond Islanders have a distinct Filipino descent bloodline with other Torres Strait Islander mixes. Some of the main families were the Sabatinos, Dorantes, Ah Wangs, Bobongies, Davids, Garniers, Ambers, Bowies and Dans. On TI itself there were distinctions between the people from Malaytown and Tamwoy Town, which still exist today. The majority of the mixed-race families lived in Malaytown on the front side of TI. Some of the Malay families that I grew up around were the Lobans, Bin Dorahos, Bin Awels, Bin Garapes, Lewins, Bin Judas, Shibasakis and Filewoods.

TI had various racial mixtures including Chinese, Japanese, Indian, Malay, Filipino, European and Aboriginal people mixed with Torres Strait Islanders, making them a really multicultural racial mix of people. I've just come back from Bali and it reminded me so much of Thursday Island when I was growing up: the resemblance of the people, the words they used, like makan for eat, talinga for ears, susu for breast, bibi for auntie, and the food markets were very similiar to the bring-and-buy food markets in the 1970s. We used to go down Yamashita's street with containers and plastic bags to buy long soup, simur chicken and coconut curry and other goodies in front of houses. The 
community and even us as kids use to take prawn baskets filled with mullet or dugong on strings of iron and sell them by the string through the neighbourhood. The Sacred Heart convent school was mainly made up of people of mixed Asian heritage and White kids; whereas the primary school was mainly kids from Waiben and Tamwoy Town and the rest of the people who weren't Catholics. It was an interesting mix. I had friends at primary school as well, who lived in my neighbourhood and we used to go down to the old Wongai basketball courts to play with them.

When we were kids, we used to go up into the bushland at the back of Summer Street, where my grandfather's brother, Uncle Petrie Ah Mat, lived next door to Uncle Talipasa Nona and his family. We used to follow Uncle Jimmy, my mother's youngest brother, to shanghai birds. We'd get one, pluck it as best we could and stick it on a piece of wood, light a fire and roast it and we would share this one little bird among four of us. As Uncle Jim was the eldest and the leader - more like our idol, who we used to all look up to and take his advice - he would decide who does what, who goes where and who gets what and how much of it. It was an honour to be allowed to follow Uncle Jim.

As there were very limited things to do as children, we used to take empty, cleaned-out food tins or plastic containers and steal fresh tar from the bitumen roads, after the council workers put it down. The boys would get old sheets of copper from the side of the house or the roof or the dump - wherever they could - and get two pieces of wood and bend the copper up making a kapa kenu (copper canoe). They would nail the wood to each end and any holes in the copper would be tarred up so the canoe would float. Then we would carry the canoe down to the beach or even the small wharf, where the baths (rock pool) were, where the local kids used to swim and sometimes test the canoes. The big wharf was mainly for the big boats and we would get in trouble if we were caught by the waterside workers. Some of the canoes sank to the bottom and I'm sure they're still down there. Well, they've probably put cement over the top of them, as it is now a car park. The more daring ones would canoe out to the buoys about 40-50 metres out from the wharf. If they got caught by the adults, they would get in big trouble and warned about sharks going to eat them.

Mango season was the best time. Mangoes used to come into season about Christmas time, the same time as the king tides, swimming season. We used to get the mangoes raw and scrape off the top where the milk comes out. We would smash the mangoes against the concrete, so they broke into pieces and then we would take them out with us in the salt water sailing and we'd keep wetting them in the salt water and eating them. It was like marinating them all day long. Those were the green mangoes - they're everywhere on TI. Then tamarind season would come along and we would get bags of tamarinds and 
shell them and put soy sauce and sugar on them and put them in big bottles and let them sit and then we would share them around the neighbourhood. I reckon these are influences from Asia. Our tastebuds are Asian, because everyone cooks with a lot of soy sauce and garlic, ginger and onion and chillies and vinegar. We eat lots of hot dishes like sambal, namas, as well as simur, curries, sopsops, dampers, kapmauris and lots of rice, to mention just a few of the Asian dishes that are commonly served at most celebrations, parties, tombstone openings, etc., and are recognised as TI recipes.

When I lived on TI in the 1970s, they had no TV, no videos and we went to the open-air 'picture show'. Friday nights featured movies with Elvis Presley and Bruce Lee and westerns with stars like John Wayne. Before each performance everyone would stand for God Save the Queen. The cinema was segregated then: upstairs was for mixed-race and White people, and downstairs was for all others. The people who sat upstairs would really dress up. I was close friends with Paula Clark and would sit upstairs with her family. At half-time everyone would rush out for snacks and quickly rush back for the next movie. When you sat upstairs you weren't watched at all but downstairs you were watched by a man with a torch, who we called Uncle Porgy. Patimah Malone used to be in the ticket box and my mother's sister, Jacqueline, also worked there as a ticket girl. Uncle Porgy stood at the door with a torch and, if he heard any noise, he would shine the torch on you, but that was for downstairs only. If you sat upstairs, you wouldn't get wet from the rain, because it was under cover. But downstairs it was open and all the lovers used to sit in the back row because they had double canvas seats for two people. By the end of the late 1970s, getting close to the 1980s, anybody could sit wherever they wanted.

By the late 1980s, when I returned to live on TI as a hairdresser, the climate felt different. I guess that was because political shifts, land claims, talk of independence and other influences of the time had changed the old TI that I once knew and loved. Although friends and family, the food, the fishing and so forth were the same, there was an influx of European government workers and more Torres Strait Islanders from the outer islands, making accommodation harder to find for the young local couples with families. The Government seems to be buying everything for either the government workers or public housing to benefit mainly the outer Islanders.

There seemed to be a slight change in attitudes: social issues were more obvious and more people sat in the pubs than went camping and fishing; more shops meant more convenience, but it seemed a real shame. The old picture theatre had closed, so more kids hung outside pubs or gathered in the parks drinking and smoking and causing trouble. There were more drinking parties when the pubs closed. 
It is not like it was before. In the pubs, the outer Torres Strait Islander people under the influence would whisper, 'What all style po, themfla no kam from dis pleis, all apkas.' They look at your skin and hair and make you feel unwelcome. In a way I'm sorry my daughter won't experience the same childhood as I had, but then again she is lucky to have the opportunity to be educated on the mainland and still learn her culture from her grandmother. She was born on TI in 1990 and identifies as a Torres Strait Islander, as she has every right to. Although people raise an eyebrow when we tell them we are from the Torres Strait and have lived the experience as Torres Strait Islanders, you can see people have trouble working out how we are descendants from the Torres Straits. But I have nothing to hide: I know where I'm from and the evidence is there running through my veins in my blood and I am proud to say who I am. My family is just one of the many true TI people from the 'old TI' and we are Torres Strait Islanders.

Wayne See Kee was born on Thursday Island and has lived in the local community for most of his life. His education was a mixture of public and private schooling on Thursday Island and in Cairns. After secondary school, he studied and completed a Bachelor of Arts in Modern Asian Studies at Griffith University in Brisbane, majoring in Chinese Language and Politics. Wayne then worked in the media industry for 10 years as a journalist, broadcaster and radio station program manager. He is employed by the Torres Strait Regional Authority, which is an Australian Government agency based on Thursday Island.

My father used to tell us stories about how hard it was for the Chinese because English for them was a second language when they first came here. I suppose it was pretty hard being Chinese, copping flack from the local people here and also the European people who were here. My father is actually third generation from Thursday Island, I think his grandparents were living here for a while and they were travelling back and forth to Hong Kong. When my father was born they got caught in Hong Kong during World War II. He told me how hard it was for them when they returned after the war, as a couple of fires went through their property and they lost everything twice and had to start from scratch on each occasion - that was really hard for them. My father only went through the first two years of secondary school and that was it, he just spent the rest of his time working. He got a lot of support from his parents and everybody helped each other until all of the family members were established and went their own way. The way of life during this period didn't give them much time to mix with other groups in the community other than through work. 
It was a lot different for me growing up, the attitudes were a lot different. I went to school here from kindy right up, primary, secondary school - half in Cairns, half here - university in Brisbane. I studied Chinese at university: I was looking for something to do, it was good fun. I didn't do it for family reasons, I did it because I did Asian studies and I majored in Chinese politics and I thought if I ever wanted to go further with this study I'd better know how to speak it. My paw-paw (grandmother) spoke Cantonese. My parents and grandparents were always working so we didn't get that exposure to them talking or my paw-paw talking. My dad's older brothers can all speak or understand Cantonese and one of them also knows Mandarin.

While I was growing up, there was also my mother's Islander background that my sisters, brother and myself needed to understand. There were our immediate relatives and other relatives who we came to know. The kinship system up here is pretty different and quite complex, the extended family is a major part of people's lives. That didn't really happen with my father's side, in the Chinese way of things. It was pretty hard to understand at a young age. It was pretty difficult actually. It wasn't until I went to uni and came back again when I was 21, 22 that I started to really understand. I found that going away for a while and talking with other people down south helped to put things in perspective and made it a lot easier to understand when I came back. My father was always working in the business, and building a future for our family. As children, we also had to work and help. Those years of working in the shop established many of the values that I carry today, especially my work ethic and team approach to doing things.

A lot of the interaction that kids get nowadays with their relatives on their Islander side we didn't get very much, because we lived on Thursday Island and would rarely see my mother's family, as many of them still lived on the outer islands or down south. We would get to see some of them when they were passing through town. For my younger brother and sister it was somewhat different, because by then the shop started to slow down and they had more contact with our other relatives, especially through high school. They also had more time to socialise because they didn't have to work in the shop like my other sister and I - it was easier for them to get to know all their relatives.

When I think back about how you don't understand both cultures properly, it's pretty hard to mix the two cultures together and sometimes you just feel like stepping back. Coming into contact with extended family who help explain things to you makes it easier to comprehend what you're in the middle of here. You start to see the forest from the trees and understand what the kinship system means, why this person is related to you, why you're supposed to call this person 'Uncle' or 'Auntie', etc. On my mother's side, you 
can go right back to three or four generations and know exactly who everybody is. I want to ensure that my kids will be more aware of their heritage than I was, because, from my experience, I have an idea of what they need to know so that they don't forget any part of their family background. I consider myself fortunate to have learned about two unique cultures in my youth and to continue to be a part of both - I get the best of both worlds.

Jason Christopher is a fourth-generation Thursday Islander of Japanese, Chinese, German and Danish origin. He was born in Cairns in 1974, but spent his childhood and early school years on Thursday Island. He is married and currently studying at James Cook University to become a pharmacist.

I was born in Cairns in 1974. My mum is a Sansei (third generation) of Japanese and Chinese origin born on Thursday Island and my dad is of Danish/German heritage born in Townsville. Nana was born in Smithton, Tasmania, to Priscilla Sherman and Andy Nielsen, timber millers. Harumi or Phylis Ahloy (née Yamashita) is my grandmother. I call her Obâsan. She is the second-oldest daughter of the Yamashita family. She married William Ahloy, a Chinese from Canton, in 1950. I was their first grandchild. Gesan (Grandad) used to show me kung-fu movies and explained them to me in English, but that was just about as far as it got with my Chinese influence other than spending time with my great uncle Ahbuck, who owned the Kowloon Restaurant in Cairns along with my Gesan. Since he passed away, I have had very little to do with the Chinese side of my cultural heritage.

I went to primary school on TI until Grade 5, when my parents tried to import us into the mainstream society in Cairns, but we were unable to adapt and returned by March of the same year. We made another attempt the next year and my mum insisted we try to adapt and kept us very busy with many different sports and activities to enable us to make friends and adapt to what was very foreign to us. In TI, because we lived 100 metres from the beach, we spent all of our spare time looking for monkey-fish, crabs, playing football and playing on the beach.

I settled in Cairns for Grade 6 onwards, first at Edgehill State School, and then in Grade 8 I moved on to Trinity Anglican High School. My parents didn't want to educate me in TI because we, as children, were not exposed to different influences. They thought we needed to have a variety to be able to learn and prosper, not in wealth, but in knowledge and the hunger to investigate the world. If there was only the TI way of living, my parents would have left us there, but we needed to go out and experience. It was not as though 
we cut ourselves off from TI: no, quite the opposite. We had the best of both worlds. Staying in TI would have restricted our knowledge and adventures. I studied Japanese at school, as they started teaching Japanese not Chinese. In Year 8, I did really well, but in Years 9 and 10 I didn't do so well. Mum said I had to continue, so I went on with it, but I nearly failed in Year 11. I wanted to go to Japan and didn't want to go to uni. I continued to have a strong interest in Japanese history and language.

After my return, I decided to go to university. I studied Japanese as part of my BA at the University of Queensland. When I finished, I went back to TI and helped my father work on the boat. I worked on TI for two years and decided to apply to go on the JET (Japan Exchange Teachers) Program. I was successful and got a position as a coordinator of International Affairs in Nonao City in Ishikawa Prefecture, where I spent three years.

On completion of my contract, I was offered an extension to stay, but my partner was not, so we decided to come back to Australia. I ran a tour company for a few months in Cairns and finally decided to get married to my partner, who is German/Australian. We moved to TI, where my wife was placed as a second-year teacher and I assisted in the bakery for my Obâsan. I then moved over to the boats and skippered our family lobster-fishing boat for some months. But things changed quickly when I was accepted into uni again. We decided to move to Townsville and I am back studying again, this time pharmacy at James Cook University. Studying is one of my hobbies. I have the need to be indulging myself with more knowledge. I hope one day to open my own pharmacy with my sister, who is studying with me.

Among my great-uncles on my maternal side, Shigeru is the only one who is strongly interested in Japan. He studied science at a Japanese university in Tokyo and married a Japanese lady, Hiroko. My oldest great-uncle married Aunty Blanche, who is of Aboriginal/Scottish descent, and has nine children. He has never left the island. The only daughter of the Yamashita family who remained on the island is my Obâsan. All the other sisters, my great-aunts, lived elsewhere after marriage. Yoshiko, who married a TI-born Japanese, moved to Sydney; Sadako married a Japanese pearl technician and now lives in Cairns; and Takeko, who was born in the internment camp, married an Englishman and now lives in Britain.

Obâsan is the strongest. She is the pillar of stability. Everything revolves around her. When something goes wrong, she is always the one who remains strong. I don't believe it, but Obâsan truly believes that she has inherited Japanese strength in her. Hours she works, very few hours she sleeps; seven days a week and 365 days a year. 
She not only runs the shop, but boats, real estate and a bakery. She must have 50 to 100 people working for her. I respect her more than anybody in the world. But there is a limit and she is getting old and she must slow down. Even though she strongly associates herself with Japanese strength and stuff, things that are happening in Japan or are said about Japan never affect her or us. She doesn't know what's going on or isn't worried about who the current Emperor is. $\mathrm{TI}$ is isolated and not much is said about Japan on TI.

TI is diverse, with lots of different ethnicities. There is no clear cut in these things. Who is 'Islander'? There is a lot of grey area - 'Australians', 'Islanders' and 'Asians'. Where does it stop and where does it start? The Yamashita family, who started out as a Japanese family more than one century ago, is now so mixed through marriage with partners of different ethnic background on the island. I have a mixed heritage - Japanese, Chinese and Danish, German - but all my life up to now, I've regarded myself as a 'Thursday Islander' because that is where my heart is. I find it a place to reflect and it is not a commercialised society. Things run according to TI time and no one on Earth will be able to change that about TI.

TI my beautiful home. TI, my home sweet home. 
Figure A: Map of South-East Asia and Torres Strait

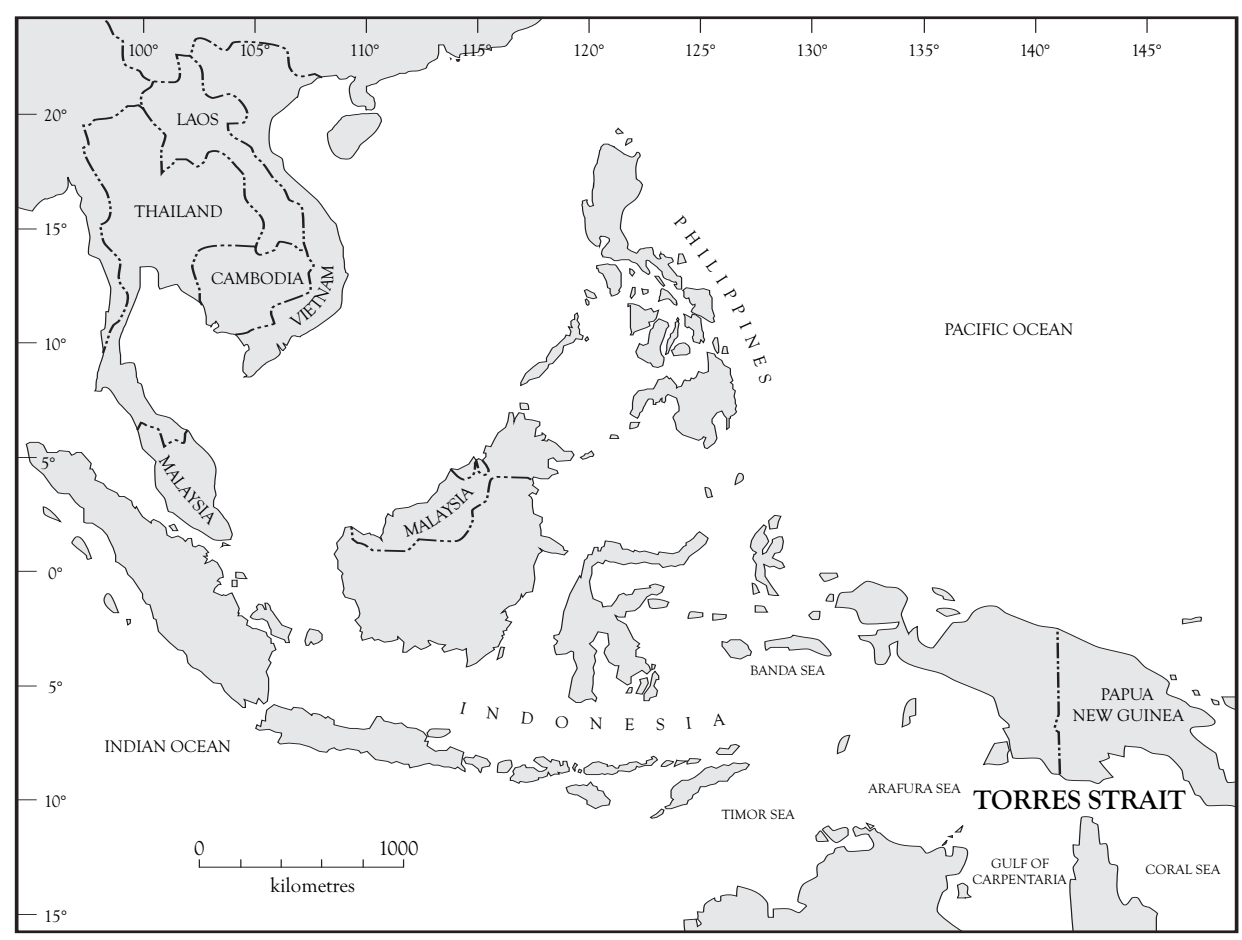




\section{Figure B: Map of the islands of Torres Strait}

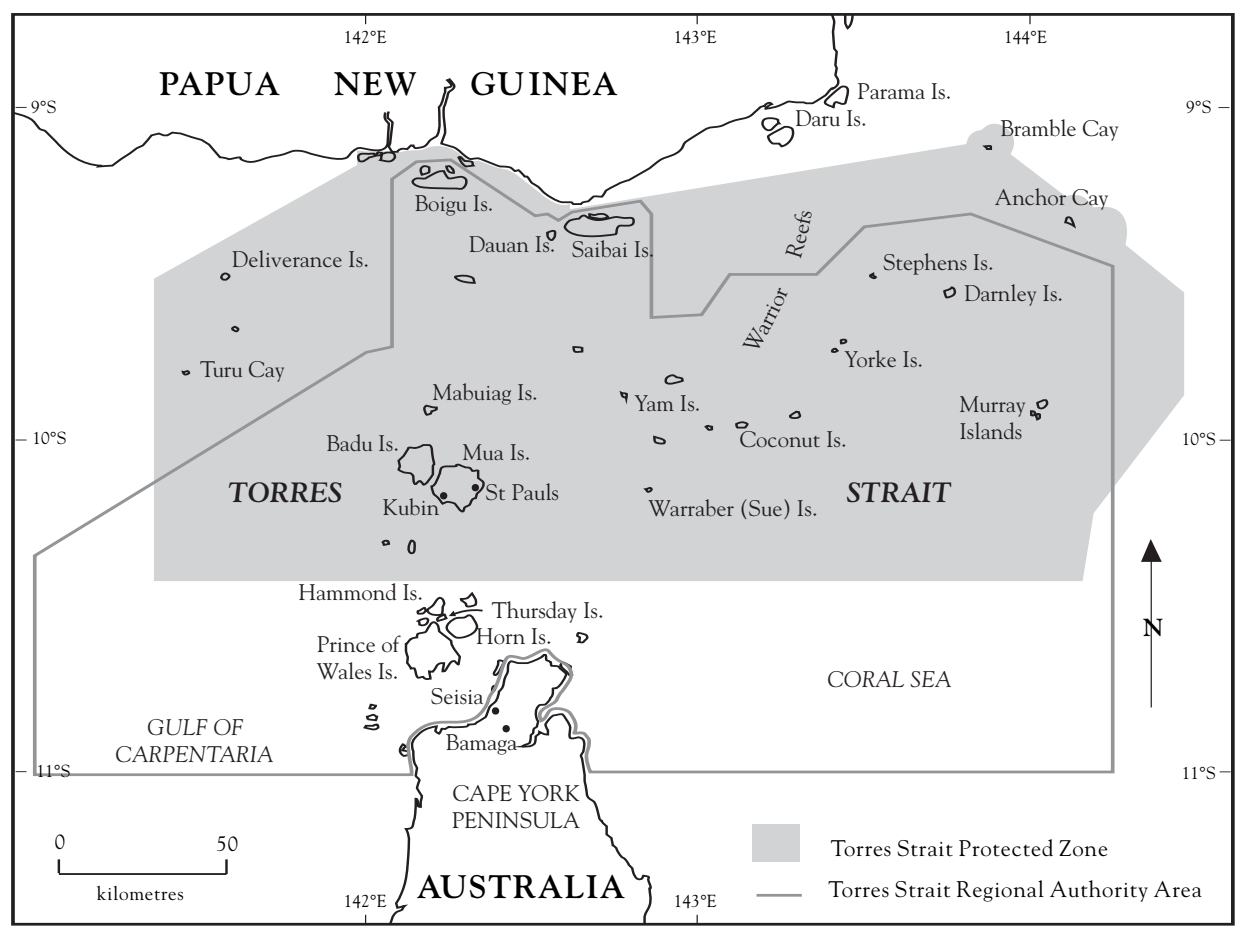


Figure C: Map of Thursday Island, 1890s

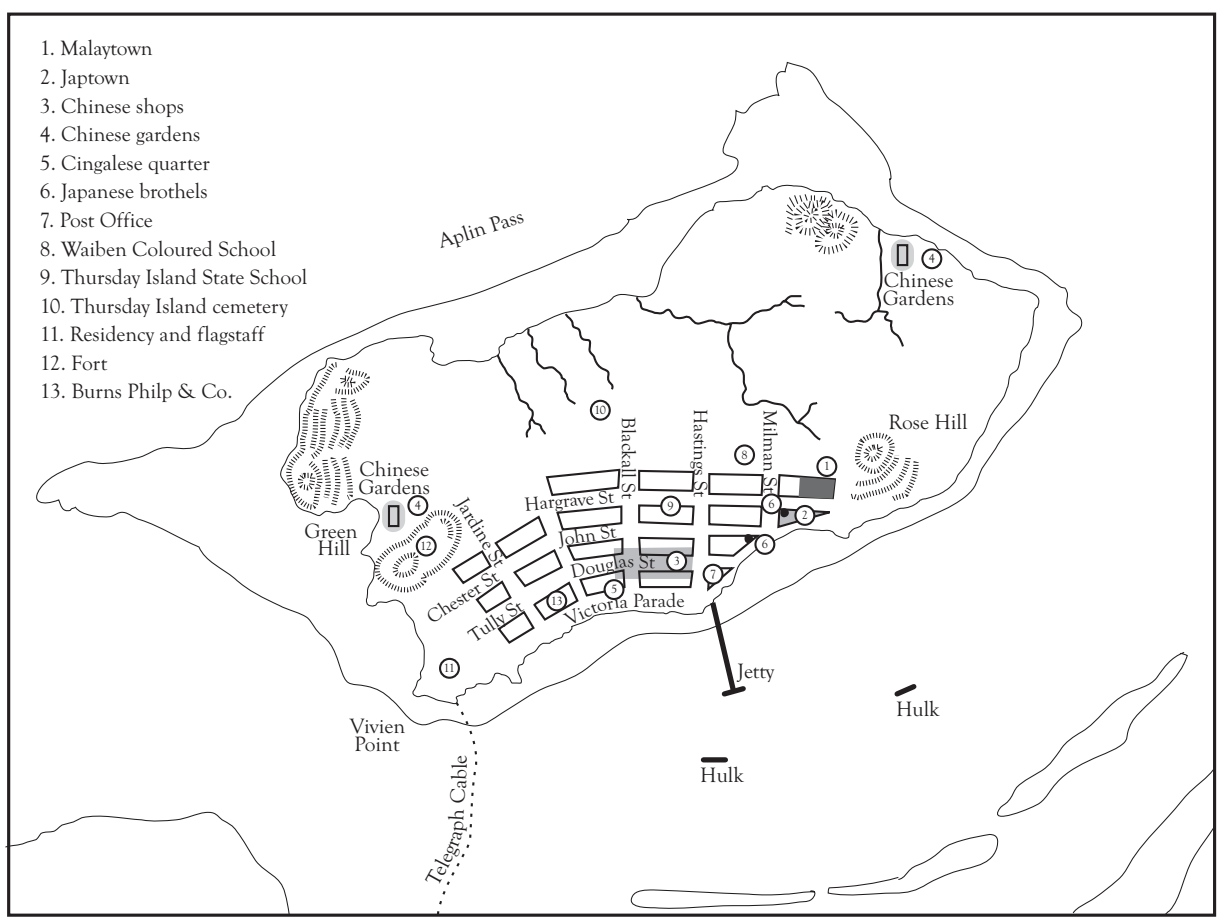

Figure D: Map of Filipino and Malay communities in Torres Strait, 1890s-1942

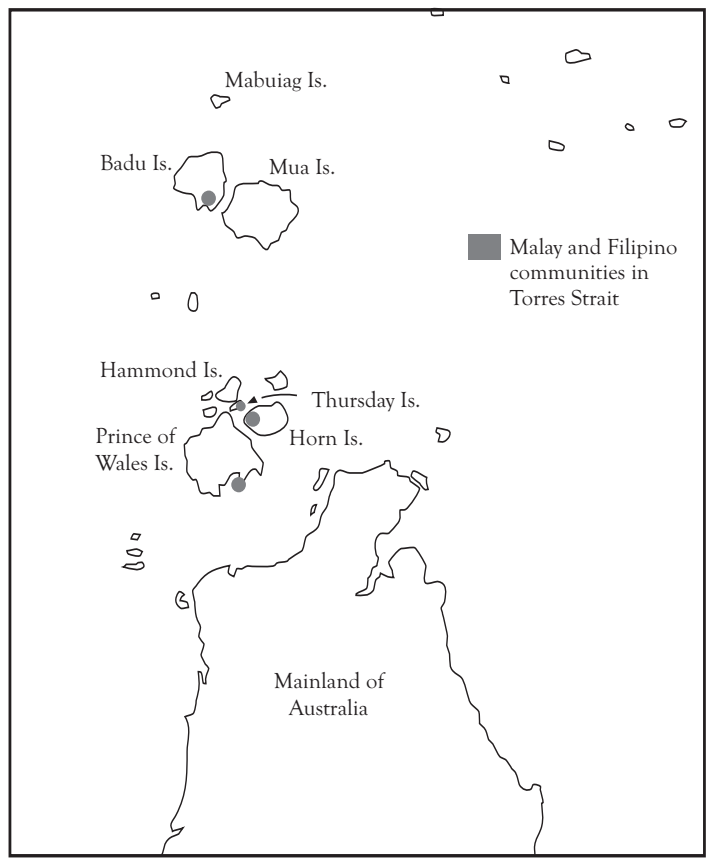

a) Horn Island was Filipino b) Port Lihou was not Malay until 1930s 
This text is taken from Navigating Boundaries: The Asian diaspora in Torres Strait, edited by Anna Shnukal, Guy Ramsay and Yuriko Nagata, published 2017 by ANU eView, The Australian National University, Canberra, Australia.

dx.doi.org/10.22459/NB.11.2017.12 